\title{
A Case Study of Using Edmodo to Enhance Computer Science Learning for Engineering Students
}

\author{
https://doi.org/10.3991/ijet.v15i03.11252 \\ Imane Ryane ${ }^{(区)}$ \\ School of Information Sciences, Rabat, Morocco \\ iryane@esi.ac.ma \\ Nour-eddine El faddouli \\ Mohammed V University, Rabat, Morocco
}

\begin{abstract}
Edmodo is becoming increasingly used in higher education. It helps teachers to easily share learning content with students, and communicate with them better. Several studies demonstrate its effectiveness in improving students' results and satisfaction with the learning process. In this paper, we describe our experience using Edmodo for courses in computer science designed for engineering students. We tested Edmodo in three courses delivered in a blended learning mode: the assembly language programming, the operating systems, and the PHP language programming. The learning scenario adopted for these courses was already presented in our previous work on the pedagogy of integration. Results show that the use of Edmodo within the pedagogy of integration enhances both learning and teaching experiences.
\end{abstract}

Keywords - Blended learning, Edmodo, mobile learning, the pedagogy of integration.

\section{Introduction}

At present, students are considered as digital natives. They were born and grew up with new technologies [1]. They click and type more than they handwrite, watch and listen more than they read. The digital native students get bored fast in the traditional education system as it is too different from the virtual world that they are used to. Their virtual world is a mix of social media, video games, and high-tech gadgets. This is why recent researches in education are focused on how to bridge the gap between school and daily life in the digital age. Some of these works showed that if we want to get the digital native students involved in a learning process, we should catch them virtually by using social media as learning tools [2], [3], [4]. The use of social media in learning facilitates the achievement of learning objectives and helps students to get better results [5]. Social media gain more and more popularity in the learning area, but one of them which is particularly accepted by students is Edmodo [6], [7].

Edmodo is part of social media used in education. It is a social networking website dedicated to learning. Its interface is similar to Facebook. This is why Edmodo is known 
as "Facebook for schools" [8]. The reason behind the similarity between Edmodo and Facebook is to facilitate the use of Edmodo by students as most of them have Facebook accounts [6]. Edmodo is free and available at www.edmodo.com. It counts more than 90 million users all over the world. Edmodo defines three profiles: student, teacher, and parent. A teacher can create a private virtual classroom protected by a unique code. Only students who have the code, can access the virtual classroom, and the content posted by the teacher. The teacher can also create notes, assignments, quizzes, and polls. He moderates the students' contributions to the virtual classroom. For students, Edmodo facilitates sharing ideas and working collaboratively [8]. It also enables them to access course materials, submit assignments and communicate with their teacher. Finally, parents can use Edmodo to follow their children's activity on the platform.

Edmodo is also available in mobile version. With the mobile app, students are notified immediately about events that happened on the platform: new posts, new assignments etc. Using mobile devices for learning is known as mobile learning (m-learning). Researches done on m-learning demonstrate its effectiveness in improving the engagement and the motivation of learners, as it provides them with more flexibility in accessing learning content [9].

In this paper, we present our experience in using Edmodo during the academic year 2017/18. We use Edmodo for courses delivered in a blended learning mode. Blended learning is a learning model that combines online and face-to-face learning activities [10]. Blended learning presents many advantages:

- It facilitates independent and collaborative learning experience

- Provides better learning outcomes

- Enables the creation of communities of inquiry

- Increases students' satisfaction with the mode of instruction [11], [12].

Our hypothesis was that using Edmodo, within the pedagogy of integration, in a blended learning mode, would improve the learning experience. The main questions that motivated this study are:

- How can we put into practice the scenario model of the pedagogy of integration for engineering students and especially in computer science courses?

- Does edmodo enhance learning and help students to get better marks?

- Does Edmodo improve students' motivation for learning?

\section{Methodology}

\subsection{Context}

This study was conducted in the school of information sciences (ESI). ESI is an engineering public school located in Rabat, the capital of Morocco. The study concerns three courses: the assembly language programming, the operating systems (OS) and the PHP language programming. We chose these courses because they were entirely delivered by the first author. We omitted other computer science courses because they were 
delivered by more than one teacher and this can bias our experience as the teacher plays an important role in the learning process. The study was carried out during the academic year 2017/18 from October 2017 to May 2018.

\subsection{Presentation of the selected courses}

Assembly language is a low programming language that enables to create powerful programs with small size and high execution speed. It is particularly used in the cyber security area and in the real-time systems. The course dedicated to this language has two objectives: understanding the internal functioning of computers, and mastering the assembly language programming. The hourly volume of face-to-face activities in this course is 16 hours, divided as presented in Table 1.

The operating systems course is a basic course for every engineering student in computer science. It aims at explaining how an OS works. It also helps students to discover the free OS Linux. 26 hours are reserved for the face-to-face activities of this course (Table 1).

The PHP course, which students appreciate most, is an opportunity to initiate students to the web development. At the end of this course, each student should create a PHP/MySQL application. To achieve this project, 32 hours are dedicated to in-class activities (Table. 1).

Table 1. Hours allocated to the selected courses

\begin{tabular}{|l|c|c|c|}
\hline \multicolumn{1}{|c|}{ Course title } & Theory (hour) & Practice (hour) & Exam (hour) \\
\hline The assembly language programming & 4 & 10 & 2 \\
\hline The operating systems & 8 & 16 & 2 \\
\hline The PHP language programming & 10 & 20 & 2 \\
\hline
\end{tabular}

Students were divided into two groups of 57 students for theory sessions and in four groups on average of 28 students for sessions dedicated to the practice.

\subsection{Learning scenario adopted for the selected courses}

For the three selected courses, we adopted the scenario model of the pedagogy of integration that we already presented in [13], [14]. The pedagogy of integration is an application of the approach by competence. It is based on the principle that after successful completion of a given curriculum, the learner should be able to solve a number of complex situations [15]. In this approach, three types of learning activities are defined:

- An elementary activity where a new learning is delivered

- An integrative activity where the elementary learning is integrated to solve complex situations

- A remediation activity where students' weaknesses are worked on 
The selected courses were delivered in a blended learning mode. In the face-to-face theory sessions, we organized elementary activities, while in the face-to-face sessions reserved to practical works, we proposed integrative activities to the students. For elementary activities, we used lecturing and didactic questioning as instructional strategies, while we preferred problem-solving strategy for integrative activities. On Edmodo, we proposed only integrative activities. Remedial activities haven't been proposed in either online or face-to-face mode (Table 2).

Table 2. The adopted learning scenario

\begin{tabular}{|l|l|l|}
\hline \multirow{2}{*}{ Type of content } & \multicolumn{2}{c|}{ Delivery mode } \\
\cline { 2 - 3 } & \multicolumn{1}{|c|}{ Face-to-face } & \multicolumn{1}{c|}{ Online (Edmodo) } \\
\hline Theory & Elementary activities & None \\
\hline Practice & Integrative activities & Integrative activities \\
\hline
\end{tabular}

\subsection{Research design and instruments}

Randolph [16] defined how experimenting can be conducted in education. For Randolph, an experiment in the education area can, for example, consist in introducing a new version of a technological tool and comparing the students' academic results between the period when they used the new version of the tool and the period when they used the old version. To answer the 2 nd and the 3 rd research questions, we used a multimethod approach for data collection:

- To measure the impact of using Edmodo, on the students' academic results, we rely on statistics related to the students' marks during the period 2016-2018. We used Edmodo as a learning tool only during the academic year 2017/18. The year before, we taught the three selected courses in a traditional way, using only face-to-face activities. We chose to compare the results between two academic years because we couldn't use Edmodo with only one group of students. Groups that wouldn't use Edmodo would consider this tool as an unfair advantage given to the others.

- In the end of the 2nd semester in 2018, we conducted an anonymous survey to determine the Edmodo's effect on students' motivation for learning. Participants included all students that followed these courses. They were 114 students with an average age of 21 years. 73 students were female representing $64 \%$ of all students. For the survey, we used a questionnaire made up of five multiple-choice and two openended questions (Table 3 ). 
Table 3. The questionnaire content

\begin{tabular}{|l|l|}
\hline \multicolumn{1}{|c|}{ Questions } & \multicolumn{1}{|c|}{ Given choices } \\
\hline Which medium did you use most to access Edmodo? & $\begin{array}{l}\text { Desktop computer } \\
\text { Laptop } \\
\text { Mobile phone } \\
\text { Tablet }\end{array}$ \\
\hline Where did you usually access Edmodo? & $\begin{array}{l}\text { At home } \\
\text { At school } \\
\text { During your journeys } \\
\text { Other }\end{array}$ \\
\hline Do you think it is easy to find course materials on Edmodo? & $\begin{array}{l}\text { Yes } \\
\text { No }\end{array}$ \\
\hline For you, what are the main advantages of Edmodo? & $\begin{array}{l}\text { Access to course materials } \\
\text { Communicate with the professor } \\
\text { Better prepare the exam } \\
\text { Edmodo isn't useful at all! }\end{array}$ \\
\hline $\begin{array}{l}\text { Do you think that the encouragement messages of your professor in- } \\
\text { creased your motivation for the courses? }\end{array}$ & $\begin{array}{l}\text { Yes } \\
\text { No }\end{array}$ \\
\hline $\begin{array}{l}\text { Which tools do you suggest to integrate into the course? } \\
\text { What are your suggestions to improve the assembly, OS and PHP } \\
\text { courses? }\end{array}$ & \begin{tabular}{l} 
Open \\
\hline
\end{tabular} \\
\hline
\end{tabular}

\section{Results}

\subsection{Students' academic achievement}

In Moroccan engineering schools, a student succeeds in a course if he obtains a mark higher or equal to $12 / 20$. If the student has a mark lower than $12 / 20$, he can pass a makeup exam. To succeed in the make-up exam the mark should also be higher than 12/20. In Table 4 we compared results obtained in the academic year 2016/17 with a traditional learning method, with those obtained in the academic year 2017/18 after the use of the blended learning scenario:

Table 4. Students' academic achievement during the period 2016-2018

\begin{tabular}{|l|c|c|c|c|}
\hline \multicolumn{1}{|c}{ Courses } & Academic Year & $\begin{array}{c}\text { \% Success in regular } \\
\text { exam }\end{array}$ & $\begin{array}{c}\text { \% Success in make-up } \\
\text { exam }\end{array}$ & $\begin{array}{c}\text { Total } \\
\text { pass rate }\end{array}$ \\
\hline Assembly language & $2016 / 17$ & 52 & 36 & 69 \\
\cline { 2 - 5 } & $2017 / 18$ & 65 & 14 & 70 \\
\hline Operating systems & $2016 / 17$ & 52 & 6 & 55 \\
\cline { 2 - 5 } & $2017 / 18$ & 64 & 6 & 66 \\
\hline PHP language & $2016 / 17$ & 64 & 55 & 82 \\
\cline { 2 - 5 } & $2017 / 18$ & 76 & 26 & 83 \\
\hline
\end{tabular}

The class size was 94 students in 2016/17 and 114 in 2017/18. For the three courses, results show that the application of the pedagogy of integration within a blended learning scenario significantly improves the success rate in the regular exam and slightly does so regarding the total pass rate. The pedagogy of integration helped students to 
gradually construct their learning while Edmodo gathered all the learning content in one place. Edmodo also enabled the teacher to provide additional support to students when it was needed. All these factors can explain the improvement of the success rate in the regular exam. Concerning the make-up exam, the use of Edmodo seems to have a negative impact. This can be probably explained by the fact that make-up exams used in 2017/18 were much more difficult than ones used in 2016/17. It should be noted that a long period, more than one month, passes between the end of the course and the makeup exam. This long period makes the revision difficult and reduces students' chances to succeed. This can explain the alarming percentage of success in the make-up exams, which didn't exceed $26 \%$ in $2017 / 18$.

\subsection{Students' motivation for learning}

In 2016/17, courses were delivered in only face-to-face mode and learning content was sent by email to students. Edmodo helped us to have a virtual space where we could share learning content and communicate with students. The content available on Edmodo, in comparison with the one sent by email is more classified, can be accessed quickly, and stored in a more secure way.

In order to answer our third research question, we conducted a survey at the end of the 2nd semester in 2018. For the survey, we used the questionnaire detailed in table 3. In table 5 we analyzed data collected by multiple choice questions (the five first questions in the questionnaire):

Table 5. Analysis of data collected by multiple choice questions

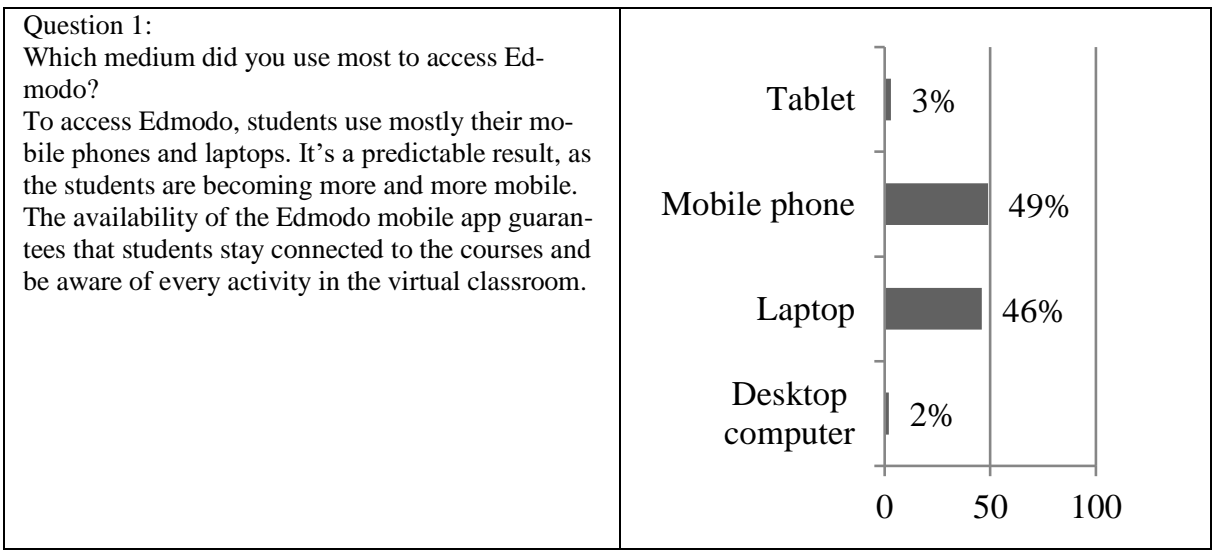




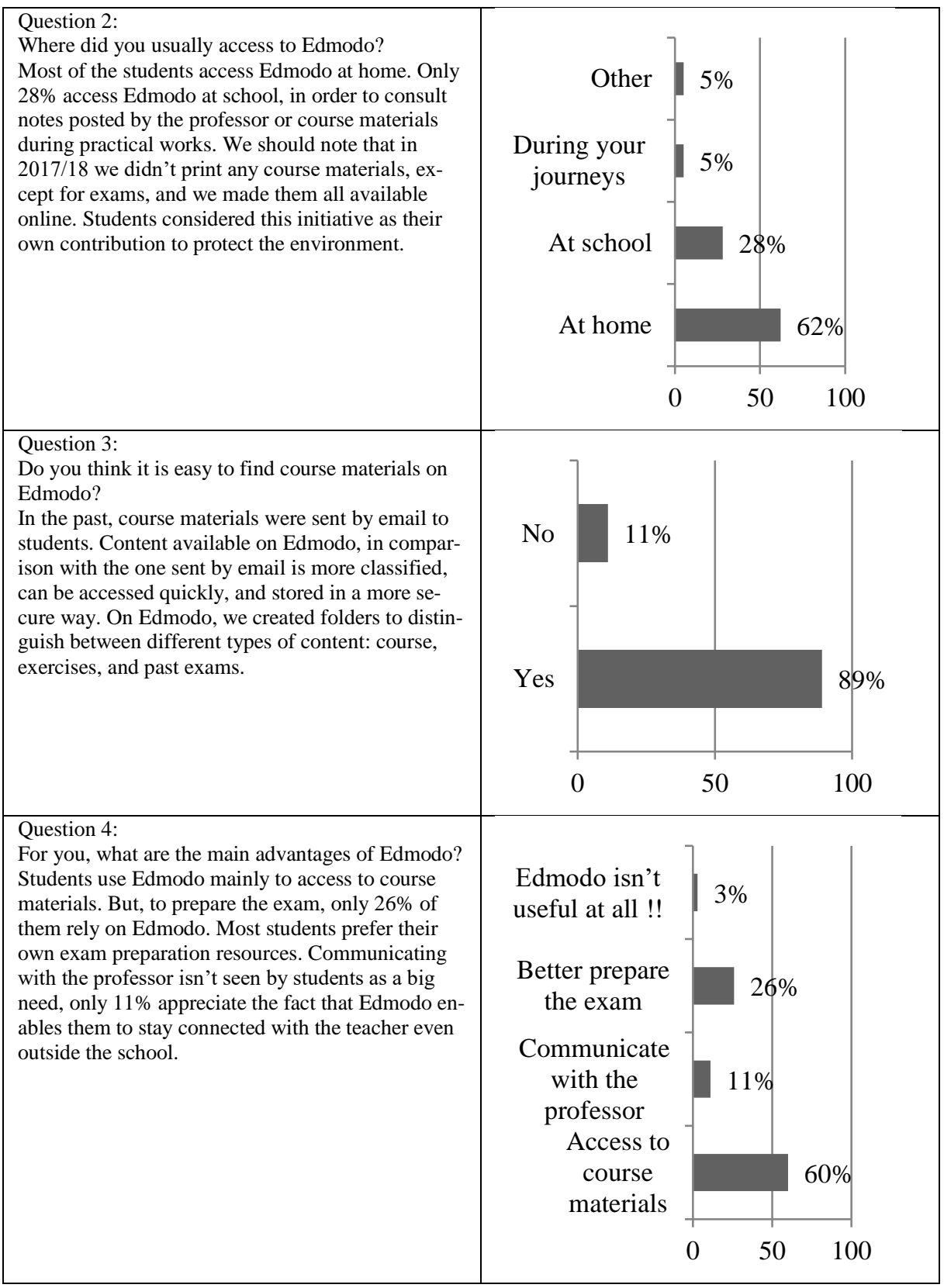




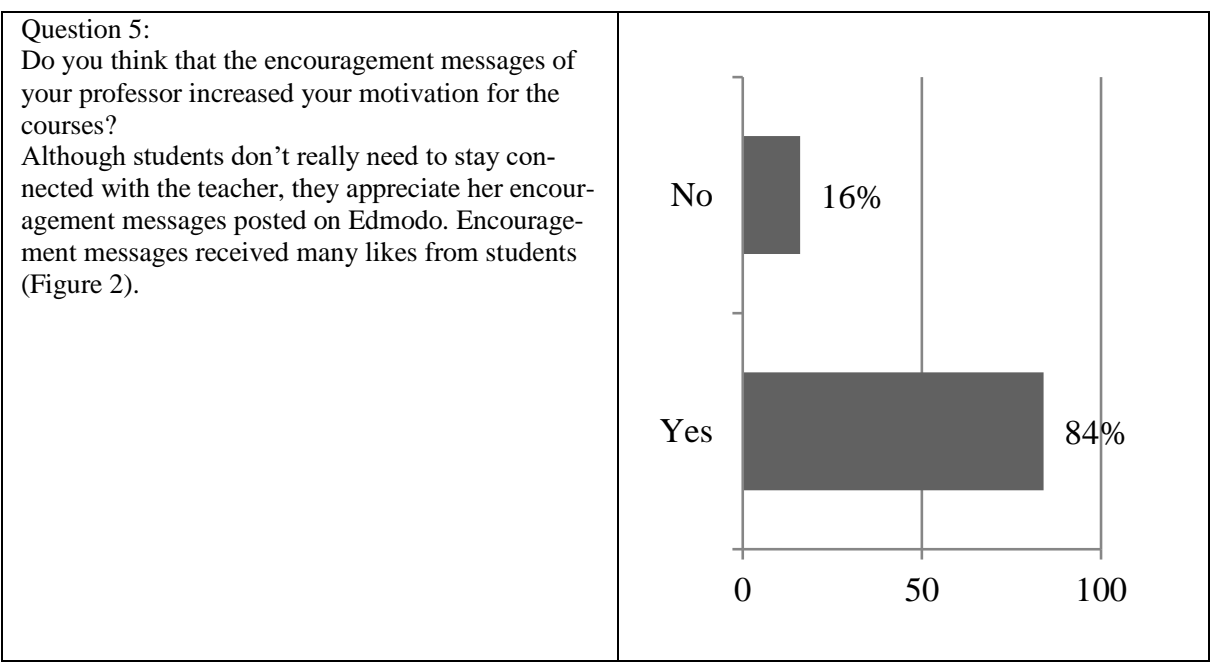

According to the results obtained in table 5, Edmodo increases students' motivation for the courses because:

- It helps them to access learning content wherever they are. Indeed, students only need the internet to access the course. They can use their laptops, or more simply their mobiles, to interact with the course content.

- It allows them to gain more self-confidence thanks to the encouragement messages posted by their professor. Furthermore, it enables them to communicate with the professor, which is considered by some students as an important advantage of Edmodo.

Results published in [17] and [18] support these findings and highlight some other key factors that explain the positive impact of Edmodo on students' motivation. Indeed, Edmodo has a Facebook-like interface. Students get quickly familiar with this environment as most of them have a Facebook account. In Edmodo, students can learn in a community and earn badges if they progress. The concepts of community and rewards are particularly present in social media and appreciated by students [19].

The last two open-ended questions helped to collect very interesting suggestions to improve the courses. We prefer to put them separately in two categories: tools and best practices.

Table 6. Students' suggestions for improving the courses

\begin{tabular}{|l|l|}
\hline \multicolumn{1}{|c|}{ Tools } & \multicolumn{1}{c|}{ Best practices } \\
\hline WhatsApp - Youtube - tutorials. & $\begin{array}{l}\text { More time for practical work. } \\
\text { Uses synthesis tables to highlight the most } \\
\text { important concepts in the course. } \\
\text { Create one virtual classroom for all the } \\
\text { courses. }\end{array}$ \\
\hline
\end{tabular}




\section{Discussion and Conclusion}

Results show that using Edmodo within the pedagogy of integration has a positive impact on students' academic achievement and enhances their motivation in computer science courses. Edmodo gives students, especially shy ones, the opportunities to send us messages. Students' messages are mostly about the exam while our responses are intended to clear confusion and encourage the student to keep working on the course (Figure 1).

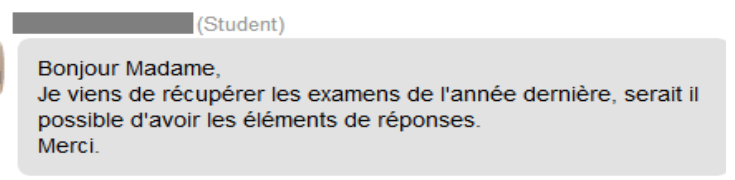

10/30/17 07:44

"Hello $X$, We will try to do the correction together this Tuesday. Good luck"
"Hello professor, I've just downloaded last year exams, can you please share the correction with us? Thank you"

\section{Bonjour,

10/30/17 09:56

Merci Madame.

"Thank you professor"

Fig. 1. A request for exam preparation resources.

We also use notes for the same purposes: clear confusion and encouragement (Figure 2).

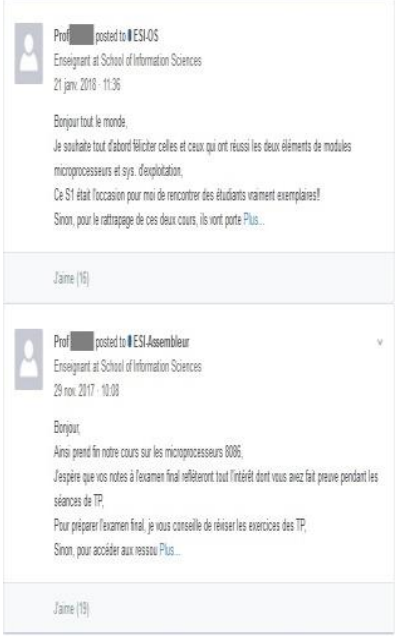

"Hello everyone, first of all I want to congratulate students who succeeded in the assembly and the OS courses. This semester was an opportunity for me to meet really great students! Concerning the make-up exam for these courses."

"Hello, we have just finished our assembly course. I hope that your marks in the final exam would be as good as your work in the practical sessions. In order to prepare the exam, I suggest you to review the exercises done in the laboratory. Otherwise, to access course materials."

Fig. 2. Examples of note 
Some students asked for help when they faced bugs (Figure 3).
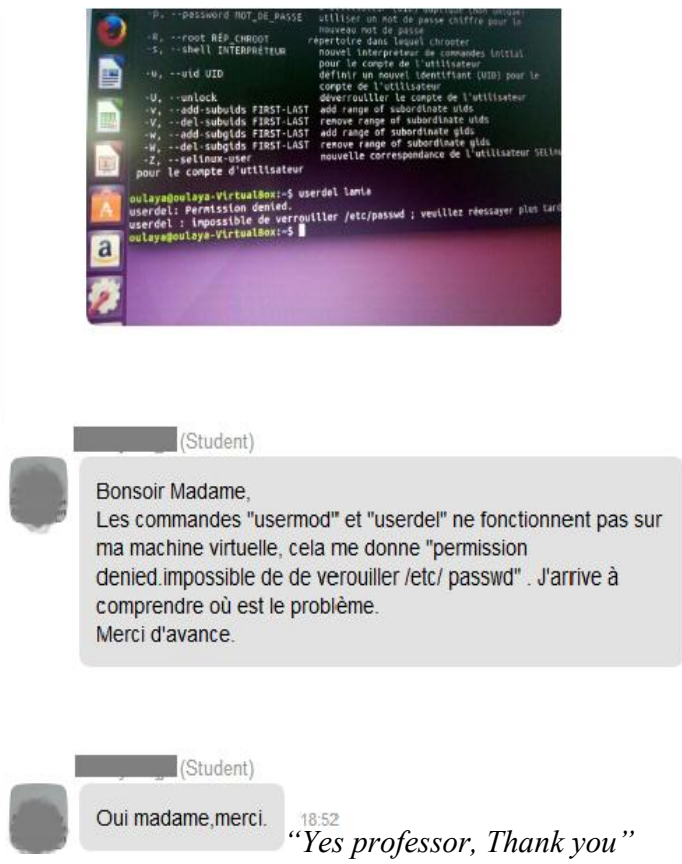

"Hello professor, the usermod and 18:23 userdel commands don't work on my virtual machine. I have this error: permission denied. Impossible to unlock /etc/passwd. I can't find out where the problem is. Thank you in advance. 18.42 C bon maintenant?

"It's OK now?"

Fig. 3. A request for help in case of bug

The study also drew our attention to the fact that the success in the make-up exam is a real issue for students. The support that we offered on Edmodo wasn't sufficient to help students to overcome this step. Perhaps the long period, more than one month, which passes between the end of the course and the make-up exam makes the revision difficult. We should probably plan a face-to-face session just some days before the make-up exam. In this session, we would work out students' weaknesses by using remedial activities.

Students' suggestions in table 4 inform about the media they prefer for learning. Students like learning by watching videos. When they faced a bug in the classroom, they look for a solution on Youtube first! We would take into consideration this parameter for upcoming courses and would propose videos and tutorials as complementary resources. We would also explore the educational use of whatsapp and how it can effectively be used in computer science courses. Finally, we would enrich course materials with tables and mind maps to facilitate learning new concepts and also the revision for the exam. This students' suggestion was already proposed by Ausubel through the concept of advance organizers [20].

Let's talk now about a person that we generally forget in education researches: the teacher. Usually, researches on Edmodo, or other innovative learning tools are mainly focused on how these tools improve the experience of learning, but rare are those who 
focused on how these tools improve the experience of teaching. With Edmodo we really enjoy teaching! Managing a virtual classroom needs much efforts and time, but in return, you deliver a course in better quality and you feel more close to students. It was a real pleasure to respond to lost students, and give them the necessary support when needed. Finally, we think that Edmodo enhances teachers' self-confidence especially for those with few years of experience like the first author of this paper.

\section{Acknowledgement}

The authors acknowledge the participation of students from the School of Information Sciences

\section{References}

[1] Prensky, M. (2001). Digital Natives, Digital Immigrants. On the Horizon, NCB University Press, Vol. 9 No. 5.

[online].http://www.marcprensky.com/writing/Prensky\%20\%20Digital\%20Natives,\%20Di gital\%20Immigrants\%20-\%20Part1.pdf

[2] Al-rahmi, W.M. Othman, M.S. and Musa, M.A. (2014). The improvement of students' academic performance by using social media through collaborative learning in Malaysian higher education. Asian Social Science, Vol. 10, No. 8, pp.210-221. https://doi.org/10. 5539/ass.v10n8p210

[3] Gikas, J. and Grant, M.M. (2013). Mobile computing devices in higher education: student perspectives on learning with cellphones, smartphones \& social media. The Internet and Higher Education, Vol. 19, pp.18-26. https://doi.org/10.1016/j.iheduc.2013.06.002

[4] Muñoz Carril, P., Álvarez De Sotomayor, I. and Gonzalez-Sanmamed, M. (2019). Social Networks and Their Uses in the Field of Secondary Education. Social Network Analytics, 203-226, 2019. https://doi.org/10.1016/b978-0-12-815458-8.00011-6

[5] Buckingham, D. and Martínez-Rodríguez, J.B. (2013). Interactive youth: new citizenship between Social networks and school settings. Comunicar, Vol. 20, No. 40, pp.10-14. https://doi.org/10.3916/c40-2013-02-00

[6] Balasubramanian, K., Jaykumar, V. and Fukey, L. N. (2014). A study on "Student preference towards the use of Edmodo as a learning platform to create responsible learning environment". Procedia-Social and Behavioral Sciences, 144, 416-422. https://doi.org/10.1016/ j.sbspro.2014.07.311

[7] Paliktzoglou, V. and Suhonen, J. (2014). Microblogging in Higher Education: The Edmodo Case Study among Computer Science Learners in Finland. Journal of Cases on Information Technology, 16(2), 39-57. https://doi.org/10.4018/jcit.2014040104

[8] Coelho, D. Galante, A. and Pires, A. L. (2016). Online Collaboration for English Learners: Implementing an International Project with Edmodo. The Electronic Journal for English as a Second Language. Vol. 19, No. 4. [online] http://www.tesl-ej.org/pdf/ej76/int.pdf

[9] Oyelere, S.S., Paliktzoglou, V. and Suhonen, J. (2016). M-learning in Nigerian higher education: an experimental study with Edmodo. Int. J. Social Media and Interactive Learning Environments, Vol. 4, No. 1, pp.43-62. https://doi.org/10.1504/ijsmile.2016.075055 
[10] Bonk, C. and Graham, C. (2006). Handbook of blended learning: Global perspectives, local designs. San Francisco, CA: John Wiley and Sons, ISBN: 978-0-787-97758-0. https://doi.org/10.5465/amle.2008.31413871

[11] BakarNordin, A. and Alias, N. (2013). Learning Outcomes and Student Perceptions In Using Of Blended Learning In History. Procedia - Social and Behavioral Sciences, 103, 577 - 585. https://doi.org/10.1016/j.sbspro.2013.10.375

[12] Garrison, D. and Kanuka, H. (2004). Blended learning: Uncovering its transformative potential in higher education. The Internet and Higher Education, 7(2), 95-105. https://doi. org/10.1016/j.iheduc.2004.02.001

[13] Ryane, I., Bentaleb, M., Khaldi Idrissi, M., and Bennani, S. (2012). Towards a better adoption of the pedagogy of integration within the Moroccan educational system. Proceeding of the 15th IASTED International Conference on Computers and Advanced Technology in Education (CATE 2012), Napoli, Italy. https://doi.org/10.2316/p.2012.774-056

[14] Ryane, I., El Faddouli, N. (2018). First step in implementing pedagogy of integration using Edmodo. Proceeding of the 12th International Conference on Intelligent Systems: Theories and Applications, 24-25 October 2018, Morocco. https://doi.org/10.1145/3289402.32895 $\underline{41}$

[15] Roegiers.X. (2010). La pédagogie de l'intégration : Des systèmes d'éducation et de formation au cœur de nos sociétés, De Boeck Supérieur, ISBN : 9782804160098. https://doi.org/ 10.3917/dbu.roegi.2001.01

[16] Randolph, J.J. (2007). Multidisciplinary Methods in Educational Technology Research and Development [online] http://justusrandolph.net/articles/multidisciplinary_methods.pdf

[17] Tsiakyroudi, M. (2018). Exploring the effectiveness of Edmodo on Greek EFL B1 learners' motivation to write. Research Papers in Language Teaching and Learning, 9(1), 96-112.

[18] Lam, Y. W., Hew, K. F., \& Chiu, K. F. (2017). Improving argumentative writing: Effects of a blended learning approach and gamification. Language Learning \& Technology, 22(1), 97-118. https://dx.doi.org/10125/44583

[19] Aldemir, T., Celik, B., \& Kaplan, G. (2018). A qualitative investigation of student perceptions of game elements in a gamified course. Computers in Human Behavior, 78, 235-254. https://doi.org/10.1016/j.chb.2017.10.001

[20] Ausubel, D. P. (1960). The use of advance organizers in the learning and retention of meaningful verbal material. Journal of Educational Psychology, 51(5), 267-272. https://doi.org/10.1037/h0046669

\section{$7 \quad$ Authors}

Imane Ryane is a professor at School of Information Sciences (ESI). ESI is an engineering school located at Rabat. She is a member of the laboratory of research in computer science and education, Mohammadia School of Engineering, Mohammed V University of Rabat, Morocco.

Nour-eddine El Faddouli is a professor at Mohammadia School of Engineering. He is a member of the laboratory of research in computer science and education, Mohammadia School of Engineering, Mohammed V University of Rabat, Morocco. elfaddouli@emi.ac.ma

Article submitted 2019-07-11. Resubmitted 2019-11-02. Final acceptance 2019-11-01. Final version published as submitted by the authors. 